\title{
Research on the Reform of Undergraduate Accounting Education and Training Mode in China
}

\author{
Xiaoli Yue \\ Shaanxi Institute of International Trade and Commerce, Xi'an 712046, China
}

Keywords: Information environment, undergraduate accounting education, personnel training mode.

\begin{abstract}
The innovation and rapid development of information technology has made great changes in accounting theory and practice. The working focus of financial accounting staff will transfer from accounting to internal control, financial analysis and risk management and other management areas. The change of external environment puts forward higher requirements for the professional knowledge and ability of accounting personnel. In addition to accounting knowledge and management knowledge, the qualified accounting personnel also need to equip with the computer operating skills, and the ability of management information system design and maintenance. In addition, the ability of accounting analysis, forecasting and decision-making using information systems are also equipped. As the main force of cultivating accounting talents, undergraduate accounting education should be reformed on the basis of professional demand, which is the key to cultivate qualified accounting personnel in the background of new environment. The undergraduate accounting education model in the information environment is taken as the research object. Combined the normative research and empirical research, the difference between supply and demand of accounting professional ability and the undergraduate accounting education talent training mode is achieved. Some measures and reforming idea are provided for the development of undergraduate accounting education in the information environment.
\end{abstract}

\section{Introduction}

Computer technology and network communication technology and other information technologies promote the society changing from industrialization to informatization. At that time, people's production methods, lifestyles and learning methods is also changing with the development of society. It can be said that the development of information technology has a far-reaching impact on human society. The accounting objective is to provide effective accounting information for the economic decision-making of the management, and the accounting information itself has a very high comprehensive characteristic. With the continuous improvement of ERP system function, the accounting work has a qualitative change. The working focus of the financial accounting staff transfers from accounting to the area of internal control, financial analysis and risk management. In the information age, the market function of accounting is mainly embodied in the object-based information input function and output function.

\section{The basic understanding of undergraduate accounting education}

\subsection{The concept of accounting education}

The accounting professional education in the level of undergraduate is the focus of China's general higher accounting education system. Students are admitted from high school graduates of higher learning unified entrance examination of the national institutions. The school system is 4 years, and students will grant a bachelor's degree in management after completing the required study.

\subsection{The composition of undergraduate accounting education model}

The education model undergraduate accounting consists of three aspects, which is undergraduate accounting education objectives, curriculum system and teaching methods. 
1) The goal of undergraduate accounting education

Generally, it includes the basic characteristics of training, training direction, training specifications and operational capacity requirements of undergraduate accounting students [3]. In fact, the educational model serves all of the educational goals, so that the education goal of undergraduate accounting is the prerequisite and basis for the curriculum system and the specific teaching method [2].

2) The teaching methods of undergraduate accounting

The basic elements that make up this method system are teachers' teaching, students' learning and information exchange. The teaching method is taken to reflect the educational goals and the expected effect of the curriculum system on students. A good teaching method will help to achieve the goal of education and the expected ability of the curriculum system, and even make up the educational goals positioning and the lack of curriculum system settings to a certain extent [4].

\section{Advantages and Disadvantages of cultivating talents in current undergraduate accounting education}

The questionnaire survey is adopted in this chapter. Through the investigation and analysis of the relevant situation of students, the advantages of training talents in current undergraduate accounting education model are understood. Therefore, through the understanding of the relevant situation of undergraduate accounting students, the education model of undergraduate accounting can be further studied and analyzed [5].

\subsection{High proactive of students on professional learning}

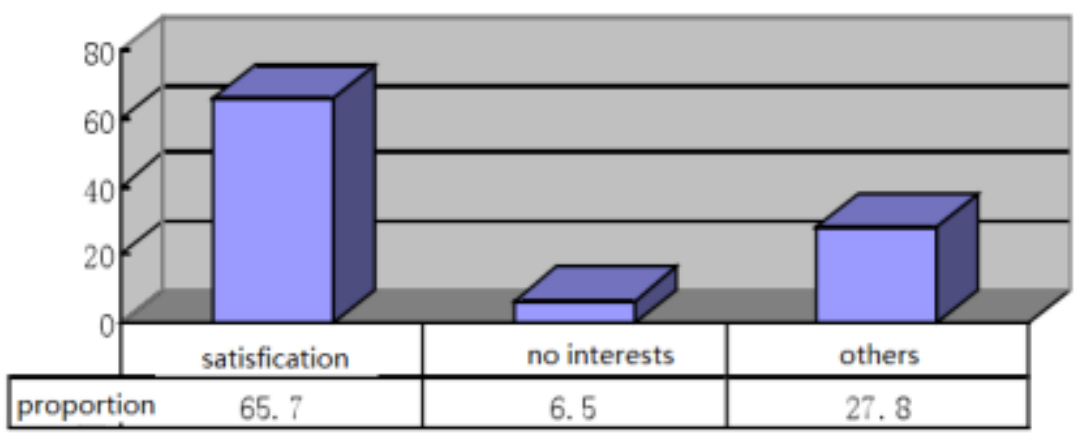

Fig. 1 The satisfaction degree of the students on the accounting profession

In Fig. 1, although $6.5 \%$ of the students are not interested in the professional, most students are still very satisfied with the professional. Through the survey, it can be seen that the less understanding of students on the professional is an important reason, but this cannot cover the efforts of undergraduate accountants to cultivate students interests in the professional. Most of the students can realize the importance of accounting and the development of China's accounting process through the teacher's explanation and their own understanding. In general, students are satisfied with the accounting profession.

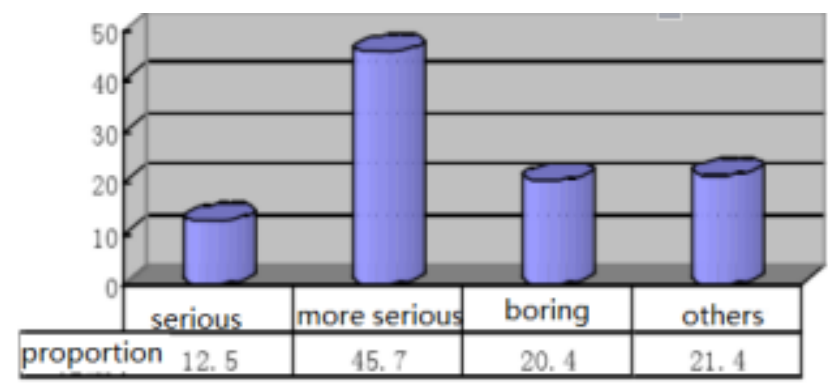

Fig. 2 Students' attitudes towards accounting courses

In Fig. 2, in addition to $20.4 \%$ of the students produce weariness due to the inelasticity for school's learning environment or the study difficulty, the learning attitude of nearly half of the students is quite correct. Most of the schools provide students with a suitable learning environment and play their own 
characteristics. Therefore, students can still correct their own learning attitude to complete their studies.

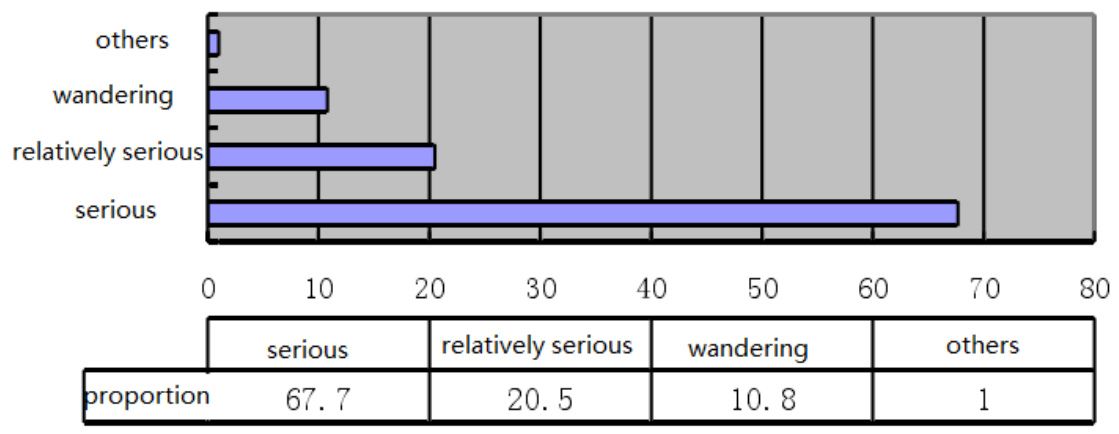

Fig. 3 A Survey of students' accounting course

In Fig. 3, the vast majority of students are more serious in class, and only about one percent of the students do not concentrate on class. The entire undergraduate accounting teaching quality can be fully guaranteed. Most teachers can choose the appropriate teaching methods and adopt effective teaching methods to attract students' attention, which fully mobilizes the learning enthusiasm of students.

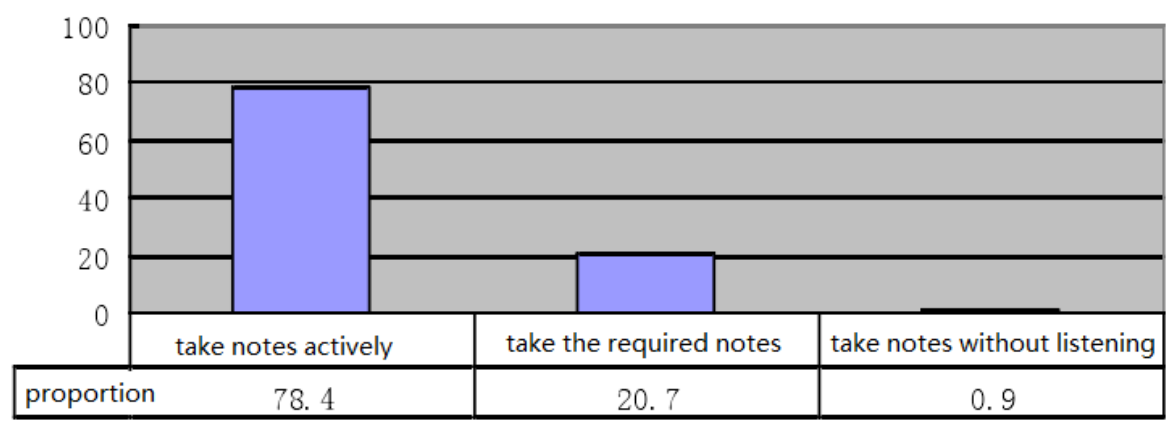

Fig. 4 A survey of student notes

In Fig. 4, nearly $80 \%$ of the students in the classroom take notes, some students only according to the requirements of teachers note notes forwardly, and less than $10 \%$ of students just listen without any records. Teachers in the classroom can give students the appropriate guidance, and students also realized that notes can help them to grasp the knowledge points. Therefore, the phenomenon of not taking notes is basically terminated.

\subsection{Statistics and analysis of survey results}

Table 1 The survey results statistics of occupational knowledge importance

\begin{tabular}{|c|c|c|c|c|}
\hline Knowledge project & $\mathrm{N}$ & $\begin{array}{c}\text { Mean } \\
\text { value }\end{array}$ & $\begin{array}{c}\text { Standard } \\
\text { deviation }\end{array}$ & Variance \\
\hline The importance of accounting, finance and knowledge & 98 & 4.4642 & 0.7311 & 0.5542 \\
\hline $\begin{array}{c}\text { The importance of economic management theory, } \\
\text { organization and business knowledge }\end{array}$ & 98 & 3.9286 & 0.6627 & 0.4392 \\
\hline $\begin{array}{c}\text { The importance of computer information system } \\
\text { knowledge }\end{array}$ & 98 & 4.0357 & 0.7445 & 0.5542 \\
\hline The importance of foreign language knowledge & 98 & 3.2142 & 0.8325 & 0.6931 \\
\hline The importance of legal knowledge & 98 & 3.8571 & 0.7052 & 0.4973 \\
\hline
\end{tabular}

From the above statistical results in Table 1, it shows that financial and accounting knowledge have the highest score and ranks first in the entire knowledge system. According to the frequency of statistical analysis, there are $60.7 \%$ of the respondents believe that accounting knowledge is very important, and $25 \%$ of the respondents believe that accounting knowledge is more important. In addition, from the statistical variance and standard deviation, the score is relatively low, indicating that the respondents were relatively consistent. 


\subsection{The results}

Through the questionnaire survey, the relevant circumstances of students taken as the local understanding of the undergraduate accounting education model are understood. And then the accounting graduates in the past two years are investigated. However, there are still some shortcomings in the undergraduate accounting education model in China. First of all, there is a less connection between China's accounting profession and the accounting education area, and there is no commanding view about the education goal of China's undergraduate accounting. Secondly, there are many problems in the curriculum system of undergraduate accounting education in our country, and the proportion of professional courses and basic courses is different. Thirdly, there are many deficiencies in case teaching, role modeling and laboratory teaching and other practical teaching methods [6].

\section{Conclusion}

Accounting is an applied discipline, so the main purpose of undergraduate accounting education is to cultivate high-quality accounting personnel to meet the needs of all sectors of society. The importance of accounting has become more and more prominent with the development of social economy. The development of accounting should keep up with economic development. Similarly, the development of accounting education should also keep up with the development of accounting practice. Accounting education should strengthen the contact with the substantive community, cultivating advanced application accounting personnel with high professional ability and judgment ability. With the continuous development of the market economy, the requirements of the society on the accounting profession have undergone tremendous changes. At present, the undergraduate education of accounting has been unable to meet the requirements of the society and the ability of the teachers, and the talent training mode reform is imperative. However, the reform of accounting education cannot be solved. With the continuous development of economic, social, management, accounting standards and education, accounting education will continue to appear new problems, then all aspects of accounting education reform also need to be adjusted. The reform of accounting education should be treated with the eye of development and change.

\section{References}

[1] Marie H. Kavanagh, Lyndal Drennan. What Skills and Attributes does an Accounting Graduate Need? Evidence from Student Perceptions and Employer Expectations [J]. Accounting and Finance, 2008, (48): 279-300.

[2] DeLange, P., B. Jackhng, A. Gut. Accounting graduates' perceptions of skills emphasis in Australian undergraduate accounting courses: an investigation from 2 Victorian universities [J]. Accounting and Finance, 2006, (46): 365-386.

[3] Jackson, S., Durkee, D. Journal of Accounting Education Incorporating information literacy into the accounting curriculum [J]. 2008, (17): 83-98.

[4] Willits, S.D. Will more liberal arts courses fix the accounting curriculum? [J]. Journal of Accounting Education, 2010, (28):13-25.

[5] Roberta L. Humphrey, Deborah F. Beard. Faculty perceptions of online homework software are in accounting education [J]. Journal of Accounting Education, 2014, (32): 238-258.

[6] Richard E. Lilliea Donald E. Wygal. Virtual Office Hours (VOH) in accounting coursework: Leveraging technology to enhance an integrative. learning environment [J]. Journal of Accounting Education, 2011 (29): 1-13. 